\title{
Introduction to the special issue "scaling up of agroforestry innovations: enhancing food, nutrition and income security"
}

\author{
Josiane Seghieri · Isabelle Droy $•$ Kiros Hadgu $\cdot$ Frank Place
}

Received: 13 September 2021 / Accepted: 13 September 2021/Published online: 21 September 2021

(C) The Author(s), under exclusive licence to Springer Nature B.V. 2021

\begin{abstract}
It is more and more acknowledged that agroecological innovations, such as agroforestry practices, should be co-created through a combination of research and traditional knowledge, be context adaptable, and meet the needs of producers and consumers. The word "innovation" recognises that agroforestry practices do exist everywhere in the world. However, to be able to effectively respond to global challenges and changes (demography and social changes, climate, local to international markets), speaking about "innovations" implies that these practices could be improved or transformed or reintroduced everywhere they had disappeared or are in decline. This reality is
\end{abstract}

J. Seghieri $(\square)$

Joint Research Unit Ecologie Fonctionnelle and

Biogéochimie Des Sols Et Des Agroécosystèmes

(Eco\&Sols), Montpellier University, French National

Research Institute for Sustainable Development (IRD),

CIRAD, INRAE, Montpellier SupAgro, Montpellier,

France

e-mail: josiane.seghieri@ird.fr

I. Droy

International Research Unit (UMI) Résiliences, French National Research Institute for Sustainable Development (IRD), Bondy, France

K. Hadgu

World Agroforestry (ICRAF), Addis Ababa, Ethiopia

F. Place

International Food Policy Research Institute (IFPRI), Washington, DC, USA still current despite the significant number of research and innovation programmes, the volume of mobilized funds and the number of participating organizations. Increasing adoption of agroforestry practices also requires long term planning and coordination because trees' life cycles are often longer than human life. This special issue includes papers on some agroforestry innovations that merit consideration for scaling up, on successful experiences that answer priorities expressed by stakeholders while taking into account their constraints, and on systemic approaches and frameworks to the development of more comprehensive perspectives on scaling up.

Keywords Adaptation · Agroecology $\cdot$ Co-created innovative practices - Livelihoods improvement . Resilience $\cdot$ Sustainable development

\section{Introduction}

Feeding the world in the context of population increase and climate change requires to scale out technologies and practices that enable more sustainable agriculture and food systems. Today, evidence is recognized on "the important contribution of agroecology in terms of: (i) enhancing smallholder and family farmers' adaptation and resilience to the impacts of climate change; (ii) improving food security and nutrition through healthy food and diversified 
diets; (iii) protecting and enhancing agro-biodiversity in support of ecosystem services such as pollination, soil health and recovery of degraded lands and forests; (iv) improving livelihoods in rural areas, and; (v) achieving a transformative change in agricultural practices towards sustainable development" (FAO 2018). Furthermore, "agroecological innovations should be people centered, meet smallholder and family farmers' and consumers' needs, be co-created, combine research and traditional knowledge, be locally adaptable, be based on open source data and technology, and enhance capacity for collective action and responsible investments" (FAO 2018).

Agroforestry is a promising agroecological option which has been practised for millennia across the world. It consists of a spatial or temporal association of trees with other annual and perennial plants, which are more often integrated with livestock, that provides multiple agroecological benefits (Zomer et al. 2016; Dollinger \& Jose 2018; Pantera et al. 2021). However, uptake and adoption of agroforestry practices require a significant boost in order to face global challenges and changes (demography and social changes, climate, local to international markets). Agroforestry practices have recently been rediscovered in the Western world, where they had been replaced by the industrial practices of the "green revolution" (Griffon 1999). At the same time, although there is a mix of experiences of increasing and decreasing tree cover in agricultural land in recent years (Zomer et al. 2016), there is a significant decrease, even where agroforestry is still currently practiced (mainly in developing countries), everywhere where rapid population growth, related urbanisation, and agriculture intensification based on mechanized monocultures occur. Similar to other agroecological options, despite the significant number of research and innovation programmes, the volume of mobilized funds and the number of participating organizations, innovations coming from research have more often failed to reach most of the beneficiaries (Albergel et al. 2018). This could be attributed to short-term perspective of governments and development agencies, often focusing on promoting technical innovations to solve immediate needs and not considering a full range of social and environmental objectives. In addition, increasing agricultural production in a sustainable way while maintaining or increasing woody land cover requires planning and coordination across several human generations because trees' life cycles are often longer than human life. Proven and scalable agroforestry research and development innovations of which applications were locally co-built with many stakeholders may help to overcome multiple constraints and to provide multiple benefits to a large number of beneficiaries, especially the most vulnerable ones (smallholder farmers, women, young people) or the ones, like migrants, who may lack long term land rights, which inhibit them from practices like agroforestry.

Indeed, scaling up implies replicating successful innovations at scale, which can be facilitated through major initiatives. Following FAO (2018) and HLPE (2019) recommendations, success of innovation scaling up requires a political commitments including transformations in policies and budgets that are long term and powerful enough to be able to catalyze deep transformations within power relations and land tenure rights that are currently big barriers to widespread adoptions. This political commitment should support " a diversity of transitions from different starting points, along different pathways, adapted to the local conditions and challenges faced in different places by different people" (HLPE 2019). This adds to the role of science the need to take into account the heterogeneity of biophysical and socio-economic contexts and aspirations across different locations. Indeed, the increasingly expected role of science is to help find a consensus to solve complex problems and deliver practical solutions through not only technical but also political, social (gender issues, for instance), and organizational innovations (Seghieri et al. 2020, this issue). Decision making based on such research results is expected to lead to design of appropriate policies and national strategies guiding accelerated uptake over a wide range of economic, social and ecological contexts.

This special issue comes from the 4th World Congress on Agroforestry, held on 20-22th May 2019 in Montpellier, France, especially from the session 8: "Scaling up of agroforestry innovations".

It aims at displaying some examples of case studies at each of three steps of the agroforestry innovation and its scaling up process:

research innovations that merit consideration for scaling up, 
successful experiences implementing expressed stakeholders' priorities while taking their constraints into account,

systemic approaches and frameworks helping to develop more comprehensive perspectives on scaling (inclusion of the most vulnerable stakeholders, current or potential traders along value chains, local authorities, etc.).

These studies come from a wide range of contexts in the world and provide scientific advances through experimental and analysis methods.

\section{Research innovations that merit consideration for scaling up}

The first pre-condition for scaling up of agroforestry practices is to have them and confirmed in a variety of targeted farm environments. For instance, it is demonstrated that ectomycorrhizae innoculations into chestnut trees seedlings in US increase seedling aboveground biomass by $16.4 \%$, generate 1.14 times more stomata on leaves (linked to carbon assimilation and $\mathrm{O}_{2}$ release), and faster recovering from an experimental drought (Aryal et al. 2020, this issue). Also planting different green manure species such as Crotalaria breviflora and Cajanus cajan with Guavira (Campomanesia adamantium), a native shrub of the Brazilian Savannah that has fruticulture potential, leads to better growth in the early stages of its development in relatively low dense areas (Gondim et al. 2020, this issue). This association seems thus to be a good option for optimizing green manure biomass and income from Guavira. These experiments may inspire trials of other approaches to enhance system productivity through agroforestry which are relevant to other regions. Gebremeskel et al. (2021, this issue) reported higher amounts of carbon stock in farms with Rhamnus prinoides based agroforestry practices compared to open farms which indicates the possibility of increasing carbon stock in farming systems through scaling up similar practices. At last, in the context of the agroforestry practice rediscovering in the Western world, Mahieu et al. (in press, this issue) propose one of the first studies reporting in details diversity in the chemical composition and digestibility of leaves in fifty native woody species or potentially adapted to temperate regions where tree leaves are still a very low source of energy, protein, vitamins and minerals for ruminants, contrary to developing countries. Authors conclude that most of woody species have a sufficient nutritive value to supplement livestock fed during summer. Some species (Morus alba, Sambucus nigra, Ficus carica, Prunus spinosa, Rubus ideaus or Passiflora edulis) show a nutritive value with high in vitro digestibility of dry matter and condensed tannins, and similar minerals concentrations to the best herbaceous fodder such as plantain and forage chicory. Due to condensed tannins action on rumen metabolism, enteric emissions, animal's health and performance, the use of woody leaves offers to temperate regions the opportunity of new nutritionally and ecologically sustainable feed resources adapted to the diversity of farming systems, pedoclimatic conditions and climatic change. Furthermore, this study paves the way to new studies to assess seasonal effect on tree leaf composition, trees productivity, and their responses to grazing or harvesting.

\section{Successful experiences implementing expressed stakeholders' priorities while taking their constraints into account}

Complementary to the demonstration of practices in a range of farmer conditions, it is currently recognized that, to maximize the adoption of these practices, it is necessary to understand and take into account the perceptions and current priorities of farmers in order to identify key actions required in the scaling up process (e.g. capacity building needs). As the bedrock of scaling up, Derero et al. (2020, this issue) advocate to first fulfil local demand (in a region of Ethiopia) by identifying the tree diversity that farmers want. Then, they tested the performance across different farm niches of six species among the ones demanded, but not available from existing tree nurseries. Finally, they generated knowledge about how to effectively supply these desired species by trainings (including farmerto-farmer exchange) that focused on tree planting techniques, protection of seedlings and post planting management derived from good practice identified in participatory trials. Kibru et al. (2020, this issue) assessed farmers' perceptions and reasons to practice Farmer Managed Natural Regeneration (FMNR) in the Tigray region of Ethiopia. They showed that FMNR, which included different techniques, has enormous 
importance in the livelihoods of the rural people. FMNR increased availability of firewood, pole, fodder, fruit and soil fertility although it faced challenges such as shortage of land, damage by animals, tree tenure security problem, distance from house, crop yield reduction, lack of knowledge and shortage of water. These challenges would need to be addressed as part of a wider scaling up strategy. Meinhold and Darr (2020, this issue) show how stimulating the emergence of local markets by using a multi-stakeholder approach (example with baobab products in Kenya), coupled with the promotion of businesses and innovations, enable local demand and markets to emerge. They demonstrate the added value of enterprise development in communities. In Peru, Lagneaux et al. (2021, in this issue) have shown the importance of maintaining exchange systems for local cocoa (Theobroma) varieties. The extension of cocoa cultivation is encouraged by public institutions. Besides the industrial varieties resulting from agricultural research and disseminated by the public authorities, many local varieties are still in circulation, used in multi-strata agro-forestry systems and exchanged between farmers. These varieties have socio-economic and environmental benefits that contribute to the diversification and resilience of local farming systems, and farmers already master them. Supporting the maintenance of this exchange and diversity would help to further increase their benefits.

\section{Systemic approaches and frameworks helping to develop more comprehensive perspectives on scaling}

Finally, several systemic approaches for scaling up agroforestry innovations are explored. The Scaling Up Initiative (FAO 2018) acknowledges that innovation for agroecology, especially to be upscaled and sustainably adopted, does need more than only the invention of new technologies or products. It entails processes through which socially and environmentally sustainable ideas, technologies, products and practices emerge thanks to interactions between a wide variety of actors (governments, civil society organizations, academia and research organizations, cooperatives, producers' organizations and the private sector). Seghieri et al. (2020, this issue) display the usefulness of the Theory of Change (ToC) and the impact pathways concepts in a research project on agroforestry in West Africa in order to monitor the project impacts, especially possible intensification initiatives during and after the project that are attractive to upscale. The project is based on a participatory approach with public, civil and private stakeholders, combined with a systemic, trans-disciplinary approach, i.e., quite beyond a technical research only. Bartlett (2020, this issue) assesses key factors behind "highly" successful agroforestry R4D projects implemented in Eastern Africa, Vietnam and Papua New Guinea. The author found that good project management, collaborative design with stakeholders and strong links to impact pathways constitute crucial internal factors. Key external factors included the existence of supportive government policies and programs including effective mechanisms for dissemination to farmers of germplasm and tree-growing knowledge.

\section{Conclusion}

So how can scaling processes be optimized in the future? Standardised public policies and programs, such as rural development policies often ignore the contexts in which they are implemented. Designing, piloting, and disseminating interventions without taking into account local contexts (biophysical, social, political, cultural, and other relevant contexts), leads to their testing and adoption often turning into a "revenge" of these contexts, which prevents all scaling up (Olivier de Sardan 2021). In this confrontation, local actors play a major role. As a result, local communities establish and follow "practical norms" that need to be understood by researchers and development organizations. Like this author, we suggest to put these "practical norms" at the centre of any intervention while valuing invisible "contextual experts". Furthermore, significant progress in scaling up agroforestry undoubtedly require resources provided by national governments and international development partners. However, these resources should be under the co-leadership of local communities or "territories" to ensure that scaling-up efforts remain aligned with local interests. 


\section{References}

Albergel J, Alpha A, Diaby N, Francis J-A, Lançon J, Sers JM, Viljoen J (2018) Bi-regional scientific cooperation on food and nutrition security and sustainable agriculture. In: Cherry A, Haselip J, Ralphs G, Wagner EI (eds) AfricaEurope research and innovation cooperation global challenges, bi-regional responses. Palgrave-Macmillan, London

Aryal P, Meiners SJ, Carlsward BS (2020) Ectomycorrhizae determine chestnut seedling growth and drought response. Agrofor Syst. https://doi.org/10.1007/s10457-020-00488-4

Bartlett AG (2020) Exploring transformational outcomes from donor investments in agroforestry research for development. Agrofor Syst. https://doi.org/10.1007/s10457-02000516-3

Derero A, Coe R, Muthuri C, Hadgu KM, Sinclair F (2020) Farmer-led approaches to increasing tree diversity in fields and farmed landscapes in Ethiopia. Agrofor Syst. https:// doi.org/10.1007/s10457-020-00520-7

Dollinger J, Jose S (2018) Agroforestry for soil health. Agrofor Syst 92:213-219. https://doi.org/10.1007/s10457-0180223-9

Food and Agriculture Organization of the United Nations FAO (2018) Scaling up agroecology to achieve the sustainable development goals. Proceedings of the second FAO international symposium. Rome. 412 pp. Licence: CC BYNC-SA 3.0 IGO

Gebremeskel D, Birhane E, Rannestad MM, Gebre S, Tesfay G (2021) Biomass and soil carbon stocks of Rhamnus prinoides based agroforestry practice with varied density in the drylands of Northern Ethiopia. Agrofor Syst. https:// doi.org/10.1007/s10457-021-00608-8

Gondim E X, dos Santos Ferreira B H, Reis L K, Guerra A, Abrahão M, Ajalla A C, Volpe E, Garcia L C (2020) Growth, flowering and fruiting of Campomanesia adamantium (Cambess) O. Berg intercropped with green manure species in Agroforestry Systems. Agroforestry Systems, DOI : https://doi.org/10.1007/s10457-020-005332

Griffon M (1999) Développement durable et agriculture: la révolution doublement verte. Cahiers Agriculture 8:259-267
HLPE (2019) Agroecological and other innovative approaches for sustainable agriculture and food systems that enhance food security and nutrition. A report by the High Level Panel of Experts on Food Security and Nutrition of the Committee on World Food Security, Rome

Kibru T, Husseini R, Birhane E, Haggar J, Solomon N (2020) Farmers' perception and reasons for practicing farmer managed natural regeneration in Tigray, Ethiopia. Agroforestry Systems, https://doi.org/10.1007/s10457-02000546-x

Lagneaux E, Andreotti F, Neher CM (2021) Cacao, copoazu and macambo: Exploring Theobroma diversity in smallholder agroforestry systems of the Peruvian Amazon. Agrofor Syst. https://doi.org/10.1007/s10457-021-00610-0

Mahieu S, Novak 1, Barre P, Delagarde R, Niderkorn V, Gastal F, Emile J-C (in press) Diversity in the chemical composition and digestibility of leaves from fifty woody species in temperate areas. Agroforestry Systems

Meinhold K, Darr D (2020) Using a multi-stakeholder approach to increase value or traditional agroforestry systems: the case of baobab (Adansonia digitata L.) in Kilifi, Kenya. Agroforestry Syst. https://doi.org/10.1007/s10457-02000562-X

Olivier de Sardan JP (2021) La revanche des contextes. Des mésaventures de l'ingénierie sociale, en Afrique et au-delà, Karthala.

Pantera A, Mosquera-Losada MR, Herzog F, den Herder M (2021) Agroforestry and the environment. Agrofor Syst 95:767-774. https://doi.org/10.1007/s10457-021-00640-8

Seghieri J, Brouwers J, Bidou JE, Ingram I, Droy I, Bastide B, Sanogo D (2020) Research and development challenges in scaling innovation : a case study of the LEAP-Agri RAMSES II project. Agrofor Syst. https://doi.org/10.1007/ s10457-020-00532-3

Zomer RJ, Neufeldt H, Xu J, Ahrends A, Bossio D, Trabucco A, van Noordwijk M, Wang M (2016) Global tree cover and biomass carbon on agricultural land: the contribution of agroforestry to global and national carbon budgets. Sci Rep 6:29987. https://doi.org/10.1038/srep29987

Publisher's Note Springer Nature remains neutral with regard to jurisdictional claims in published maps and institutional affiliations. 